\title{
New era dawns for US stem cell research
}

Ten years ago, the future of medicine changed forever - the distinct possibility emerged that we could achieve cures for many serious diseases or injuries that would otherwise require life-long therapies. It was in November 1998 that Jamie Thomson and his team at the University of Wisconsin first reported the successful derivation and sustainable culturing of human embryonic stem cells [1]. Whilst this remarkable achievement gave hope to millions of patients it also led to a storm of public and political debate. The most high profile being the televised address to the American nation by President Bush on the evening of August 9th 2001 [101]. In his short communication of approximately 1700 words, the President set out his view of the debate surrounding human embryonic stem cells and the future deployment of US federal funds. He "concluded that we should allow federal funds to be used for research on these existing stem cell lines, where the life and death decision has already been made". Not a total ban, and indeed by July 2006, President Bush declared, possibly even with pride, that his administration had "made available more than $\$ 90$ million for research on these lines. This policy has allowed important research to go forward..." [102]. However, overall the federal policy was deemed by many experts to put the USA at a tremendous disadvantage in the global stem cell race. A recent interview with one of the early trailblazers, John Gearhart (University of Pennsylvania), best sums-up the sentiment of the sector, "The truth is that the US's position as a leader in this field is at risk; federal policy has really limited us in terms of competing with many foreign countries..." [2].

Americans being Americans with their strong 'can-do' attitudes, resulted in many enlightened individuals championing the stem cell cause during the subsequent wilderness years. To mark the third anniversary of the launch of the journal Regenerative Medicine, this issue contains interviews with three stem cell pioneers who are internationally recognized to be at the forefront of their respective sectors; Bob Klein, Governor Jim Doyle and Bernie Siegel [3]. All three are outstanding leaders and between them they represent the necessary strong pragmatism to get the job done coupled with real vision as to the power of stem cells for the benefit of both patients and society.

\section{Financial \& competing interests disclosure}

The authors have no relevant affliations or financial involvement with any organization or entity with a financial interest in or financial conflict with the subject matter or materials discussed in the manuscript. This includes employment, consultancies, honoraria, stock ownership or options, expert testimony, grants or patents received or pending, or royalties.

No writing assistance was utilized in the production of this manuscript.

\section{Bibliography}

1 Thomson JA, Itskovitz-Eldor J, Shapiro SS et al.: Embryonic stem cell lines derived from human blastocysts. Science 282 (5391), 1145-1147 (1998).

2 Wolinsky H: A decade of stem-cell research. An interview with John Gearhart, Director of the Institute for Regenerative Medicine at the University of Pennsylvania, USA. EMBO Rep. doi:10.1038/embor.2008.235 (2008) (Epub ahead of print).

3 Klein RN, Doyle J, Siegel B: It's all about change ... regenerative medicine in the Obama era. Regen. Med. 4(1), 27-32 (2009)

\section{Websites}

101 Bush GW: President Discusses Stem Cell Research (2001). www.whitehouse.gov/news releases/2001/08/20010809-2.html

102 Bush GW: President Discusses Stem Cell Research (2006). www.whitehouse.gov/news/releases/2006/07/20060719-3.html

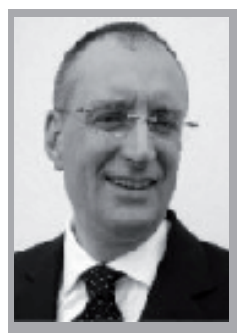

Chris Mason Author for correspondence: Advanced Centre for Biochemical Engineering, University College London, Roberts Building, Torrington Place, London, WC1E 7JE, UK

Tel.: +44 2076790140 ;

Fax: +44 207209 0703; E-mail:chris.mason@ucl.ac.uk

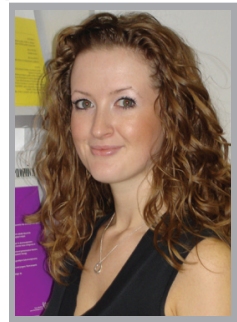

Elisa Manzotti

Future Medicine Ltd,

Unitec House, 2 Albert Place,

Finchley Central, London,

N3 1QB, UK

Tel.: +44 2083492033

Fax: +44 208343 2313;

E-mail: e.manzotti@

futuremedicine.com;

www.futuremedicine.com 